giving potassium supplements to elderly patients where their need is not urgent. Since the absorption of fluid from the infusion site is slow, we do not recommend this method for giving potassium when large amounts are needed urgently. There seems to be no danger of hyperkalemia with the method used here.

Although hypodermoclysis is suitable for use in nursing homes, we feel that subcutaneous potassium infusions should be given only in hospitals until more experience is gained.

We would like to thank Cilla Gerber, Ilana Elroy, and the other members of the nursing staff for their help and co-operation.

1 Schen RJ. Subcutaneous infusions in the elderly. Br Med $f 1981$;282:823-4. 2 Schen RJ, Edelstein-Singer M. Subcutaneous infusions in the elderly. f Am Geriatr Soc $1981 ; 29: 583-5$.

3 Simpson RG. Hyaluronidase in geriatric therapy. Practitioner 1977;219: 361-3.

- Elkington JR, Tarail R. The present status of potassium therapy. Am $\mathcal{J}$ Med 1950;9:200-7.

5 Judge TG. The milieu intérieur in aging. In: Brocklehurst JC, ed. Textbook of geriatric medicine and gerontology. 2nd ed. Edinburgh: Churchill Livingstone, 1978:117-24.

(Accepted 24 Fune 1982)

Department of Geriatric Medicine, Tel-Aviv Medical Centre, Ichilov Hospital, Tel-Aviv, Israel

RAFAEL J SCHEN, MB, BS, director

SHLOMO ARIELI, MD, assistant physician

\section{Estimation of urine specific gravity and osmolality using a simple reagent strip}

A recently developed reagent strip, now incorporated into an existing multiple test strip, provides a guide to urine specific gravity and osmolality and is quicker and simpler to use than the traditional methods of assessing urinary concentration. This method requires only a small volume of urine and is therefore an improvement on hydrometry, which is not always practical in patients with reduced urine volumes, from whom results are often of most interest. ${ }^{1}$ The new strip was evaluated against traditional methods.

\section{Methods and results}

The strip test now incorporated on N-Multistix SG (Ames), is based on the pKa change of pretreated polyelectrolytes in relation to the concentration of cations in urine. Fresh urine was obtained from healthy controls, medical inpatients, diabetic patients with glycosuria, and patients with serious renal disorders. The urine was tested by the strip method; specific gravity was also measured by hydrometry and refractometry and osmolality by freezing-point depression.

There were satisfactory correlations between specific gravity as measured by hydrometer and by the strip in all groups except diabetics with $2 \%$ glycosuria (specific gravity measured traditionally does not reflect osmolality in patients with glycosuria) (correlation coefficients : controls 0.93 , all patients 0.83 , individual patient groups $0.80-0.86$, diabetics 0.78 ). Osmolality as measured by traditional methods and by the strip correlated well in diabetics, with $85 \%$ strip agreement to within 0.005 with osmolality classification there were reasonable correlations in other groups (coefficients: controls 0.90 diabetics $0 \cdot 82$, all patients $0 \cdot 78$ ). Measurements of refractometry correlated well with results of the strip test in all groups.
The table shows results of strip tests compared with those of traditional w methods.

\section{Comment}

The correlations between results of traditional methods and those of the new strip test suggest that the strip test provides similar $D$ information more quickly and more easily. In most of the few patients $\mathbb{D}$ with a discrepancy between results of hydrometry, refractometry, $m$ tests of osmolality, and strip testing this was unlikely to be misleading, as in clinical practice urines are classified as "concentrated," "isotonic," or "dilute."

An unexplained overestimate of strip specific gravity in three patients with rejecting kidney transplants merits further investigation. Clinical experience may show other examples of non-correlation: these are no more likely to be clinically confusing than any other traditional tests when used in isolation from other information to make major decisions.

The "specific gravity" estimated by $\mathrm{N}$-Multistix SG appears a satisfactory alternative to ward testing by hydrometry. It will save nursing time-and perhaps money, as hydrometers break. In patients with diabetes and heavy glycosuria the strip is an improvement on hydrometry and refractometry, and with other patients it is more $O$ convenient. The new test allows assessment of urine concentration when only small volumes of urine are available. In textbooks describing hydrometry, ${ }^{23}$ corrections are suggested for temperature, protein, and of glucose; a pH correction is recommended by the manufacturers of the strip. In our opinion these correction factors provide a precision not usually needed in clinical practice. Infected urine (often detectable by the nitrite test on these strips) or urine with a high $\mathrm{pH}$ may be stale, and results should be interpreted with caution.

Measurement of specific gravity by hydrometry is a task often $O$ "routinely" performed by nursing staff, but with results rarely used and sometimes not understood by medical staff. It is also, by tradition, part of many examinations for insurance, employment, and other purposes. Osmolality should be measured in problem patients, but few laboratories are prepared to process large numbers of specimens, and there is limited enthusiasm for out-of-hours requests: measurement of urine osmolality should not be a "routine" investigation. Information on urine concentration, however, may be useful and $N$ patients might receive inappropriate fluid regimens less often if doctors used the information on urine concentration collected for them by the nursing staff. The introduction of strip testing may stimulate doctors to consider more carefully how to use measurements of urine concentration and make it much easier to measure at the bedside.

We thank Dr A M J Woolfson for advice and help, Miles Laboratories for supplies of N-Multistix SG, and nursing staff and patients for cooperation in collection of urine samples.

1 Anonymous. Acute renal failure. $\mathrm{Br}$ Med $\mathcal{f} 1980 ; 280: 1333-5$.

2 Bomford R, Masser S, Swash M, eds. Hutchison's clinical methods. London: Baillière Tindall, 1975.

3 Henry RJ. Clinical chemistry, principles and techniques. London: Harper and Row, 1966.

(Accepted 6 August 1982)

Renal Unit and Department of Clinical Chemistry, City Hospital, Nottingham NG5 1PB

A J FREW, BA, MB, senior house officer

J MCEWAN, BSC, MB, senior house officer

G BELL, AIMLs, medical laboratory scientific officer

M HEATH, MPHI, FIMLS, chief medical laboratory scientific officer M S KNAPP, MD, FRCP, consultant physician

\begin{tabular}{|c|c|c|c|c|c|c|c|c|c|c|c|c|c|c|c|}
\hline \multirow{2}{*}{ Strip } & \multicolumn{7}{|c|}{ Hydrometer reading } & \multicolumn{8}{|c|}{ Osmolality (mOsm/kg) } \\
\hline & $\begin{array}{l}1.000- \\
1.002\end{array}$ & $\begin{array}{l}1.003- \\
1.007\end{array}$ & $\begin{array}{l}1.008- \\
1.012\end{array}$ & $\begin{array}{l}1.013- \\
1.017\end{array}$ & $\begin{array}{l}1.018- \\
1.022\end{array}$ & $\begin{array}{l}1.023- \\
1.027\end{array}$ & $\begin{array}{l}1.028- \\
1.032\end{array}$ & ${ }_{75}^{0-}$ & $\begin{array}{c}75- \\
225\end{array}$ & $\begin{array}{l}226- \\
375\end{array}$ & $\begin{array}{l}376- \\
525\end{array}$ & $\begin{array}{l}526- \\
675\end{array}$ & $\begin{array}{l}676- \\
825\end{array}$ & $\begin{array}{l}826- \\
975\end{array}$ & $976+$ \\
\hline $\begin{array}{l}1.000 \\
1.005 \\
1.010 \\
1.015 \\
1.020 \\
1.025 \\
1.030\end{array}$ & $\begin{array}{l}1 \\
8 \\
0 \\
0 \\
0 \\
0 \\
0\end{array}$ & $\begin{array}{r}0 \\
10 \\
19 \\
2 \\
0 \\
0 \\
0\end{array}$ & $\begin{array}{r}0 \\
2 \\
12 \\
11 \\
3 \\
0 \\
0\end{array}$ & $\begin{array}{l}0 \\
0 \\
3 \\
5 \\
6 \\
3 \\
0\end{array}$ & $\begin{array}{l}0 \\
0 \\
2 \\
3 \\
4 \\
3 \\
4\end{array}$ & $\begin{array}{l}0 \\
0 \\
2 \\
1 \\
2 \\
1 \\
3\end{array}$ & $\begin{array}{l}\mathbf{0} \\
\mathbf{0} \\
\mathbf{0} \\
\mathbf{0} \\
\mathbf{1} \\
\mathbf{0} \\
\mathbf{0}\end{array}$ & $\begin{array}{l}0 \\
1 \\
0 \\
0 \\
0 \\
0 \\
0\end{array}$ & $\begin{array}{l}1 \\
3 \\
0 \\
0 \\
0 \\
0 \\
0\end{array}$ & $\begin{array}{r}0 \\
12 \\
16 \\
2 \\
1 \\
0 \\
0\end{array}$ & $\begin{array}{r}0 \\
3 \\
12 \\
7 \\
2 \\
0 \\
0\end{array}$ & $\begin{array}{l}0 \\
1 \\
8 \\
8 \\
7 \\
2 \\
0\end{array}$ & $\begin{array}{l}0 \\
0 \\
2 \\
4 \\
3 \\
2 \\
4\end{array}$ & $\begin{array}{l}\mathbf{0} \\
\mathbf{0} \\
\mathbf{0} \\
\mathbf{1} \\
1 \\
3 \\
1\end{array}$ & $\begin{array}{l}0 \\
0 \\
0 \\
0 \\
2 \\
0 \\
2\end{array}$ \\
\hline
\end{tabular}

